\title{
BURKING: A CASE REPORT
}

D. Durga Prasad ${ }^{1}$

\section{HOW TO CITE THIS ARTICLE:}

D. Durga Prasad. "Burking: A Case Report". Journal of Evolution of Medical and Dental Sciences 2014; Vol. 3, Issue 39, August 28; Page: 9959-9963, DOI: 10.14260/jemds/2014/3291

\begin{abstract}
Homicide means causing death of a person by another person. This homicide may be lawful or unlawful. There are many ways of committing a homicide. Burking is one of the methods. The term 'Burking' is derived from notorious criminal 'Burke', who with his accomplice 'Hare', killed old people by a combination of smothering and traumatic asphyxia, and sold the bodies to the medical school in Edinburgh. We here presented a case of homicide by burking. AIM: To explain the term burking and to present a real case of homicide by burking, which we encountered. MATERIALS \& METHODS: Various journal articles, textbooks of Forensic Medicine, FIR copy of the case, crime scene visit, photos, inquest report, post mortem examination, crime investigation information. CONCLUSION: Burking is a type of homicide by smothering with traumatic asphyxia. Though it is rare, it is not completely unseen.
\end{abstract}

KEYWORDS: Homicide - Burking - Smothering with Traumatic asphyxia - a case report.

INTRODUCTION: Homicide means causing death of a person by another person. This homicide may be lawful or unlawful. Lawful homicide includes justifiable and excusable homicides. Unlawful homicide includes murder (S.300.IPC), culpable homicide not amounting to murder (S.299.IPC), culpable homicide amounting to murder (S.304A.IPC), rash or negligent homicide (S.304A.IPC). ${ }^{1}$

There may be several reasons for committing a murder, like jealousy, rivalry, infidelity, want of money (burglary), unsoundness of mind, war, so on. The method chosen to commit a homicide is equally varied, like shooting, stabbing, beating, poisoning, fire, asphyxia, shaken baby syndrome, vehicular accidents, etc. as per survey by Canadian Centre for Justice Statistics, stabbing, shooting \& beating were the common methods of homicide during 2008-2012. Asphyxia is less common method and accounted for $8 \%$ of the homicides in Canada. Burking, being one of the several methods of asphyxia, is a much more infrequent finding. ${ }^{2}$

REVIEW OF LITERATURE: Literally the term 'asphyxia' denotes absence of pulsations, though its usage in forensic medicine has generally come to mean a lack of oxygen. Actually asphyxia is best described as an interference with respiration due to any cause - mechanical, environmental or toxic.

\section{Asphyxia may be caused due to:}

- Closure of external respiratory orifices (smothering),

- Occlusion of air passages by pressure on neck (hanging, strangulation, throttling),

- Occlusion of air passage from within (chocking),

- Lack of oxygen in the atmosphere, or inhalation of irrespirable gasses (suffocation),

- Restriction of respiratory movements of the chest or abdomen (traumatic asphyxia),

- Prevention of gas exchange in the lung fluids (drowning),

- Inability to utilise oxygen by the peripheral tissues (poisoning). 
In smothering, death is due to mechanical occlusion of mouth or nose, for instance by pressing a pillow or any soft material over the mouth and nose, or by manually closing these orifices.

In traumatic asphyxia, death results from pressure fixation of the chest and/or abdomen. Because of pressure on the chest, the victim is unable to breathe and dies of asphyxia. Burking is a method of homicidal smothering with traumatic asphyxia.

The term 'Burking' is derived from notorious criminal 'Burke', who with his accomplice 'Hare', killed old people by a combination of smothering and traumatic asphyxia, and sold the bodies to the medical school in Edinburgh. In early part of 19th century, in England, a criminal trade flourished relating to the sale of dead bodies to the medical schools.

To plug the acute shortage of cadavers, a special breed of individuals emerged who came to be known as 'Resurrectionists'. They used to dig out freshly buried bodies from cemeteries and supply them to anatomists for a hefty price. Burke and Hare, who used to supply to The Edinburgh Medical School, decided to kill people regularly, thereby doing away with the element of chance altogether. The modus operandi consisted of roaming the disreputable parts of the city in nights.

They would invite the poor homeless victim to their living quarters with promises of drink, food and merriment. As soon as the guest was drunk enough, Hare would wrestle him to the floor and close his mouth and nostrils with his hands, while Burke would sit on the poor victim's chest, a combination of intoxication, smothering and traumatic asphyxia. They later got arrested. Burke was publicly hanged (lawful homicide!)..$^{3,4}$

CASE DETAILS: A 65 year old female was found dead in her home on bed, at about 3.30pm on $1 / 07 / 2014$. Post mortem was conducted over the body of the deceased on $2 / 7 / 2014$. The body was lying flat on the post mortem table on its back. Pm hypostasis is seen on the back of the body. Copious blood stained fluid is seen at angles of mouth and nostrils. Both eyes showed petechial hemorrhages over sclera. Finger nail bed shows cyanosis.

A $2 \times 2 \mathrm{~cm}$ reddish abrasion on outer aspect of lower lip and a reddish abrasion of $2 \times 2 \mathrm{~cm}$ below chin were seen. Inner surface of both lips were contused. Internally, 2-6 left side ribs were fractured, with hematoma into surrounding intercoastal muscles. All organs were congested. Right side heart was dilated and blood filled. Cause of death was opined as death due to Burking (smothering+traumatic asphyxia).

CCS police took over the case and caught the 3 young male, who entered the house. They confessed that on entering the house, one person sat over the chest of the woman who was sleeping, other smothered her. The police further found out that they were a gang of 8 engineering students, who got addicted to luxury and adapted to burglary for easy money.

The modus operandi was to choose old people, who live alone, kill/beat them and to rob them. They were successful in 13 previous cases, but got caught in this case, though they refined their method of homicide.

DISCUSSION: The body of the deceased showed copious secretions at mouth angles \& nostrils, petechial hemorrhages on the sclera of eye balls, acral cyanosis, congested internal organs and dilated right side of the heart. These were asphyxial signs. Other signs of asphyxia which may be found in other cases are severely congested face, abnormal fluidity of the blood, ligature mark around neck, finger nail abrasions on the neck, fluid in air passages and stomach, foreign body in larynx, etc., as per the type of the case. ${ }^{5}$ 


\section{CASE REPORT}

The body also showed abrasions around mouth, contusions on the inner surface of lips indicating smothering. Rib fractures showed chest trauma causing traumatic asphyxia.

So this is a case of burking which means of homicide by smothering with traumatic asphyxia. This is an effective way to cause easy, quick, non-messy death and is usually employed over children or old people. ${ }^{6}$

CONCLUSION: Burking is a type of asphyxia, though rare, is not totally an unseen method. Habitual criminals may refine their technique to this effective method Burking.

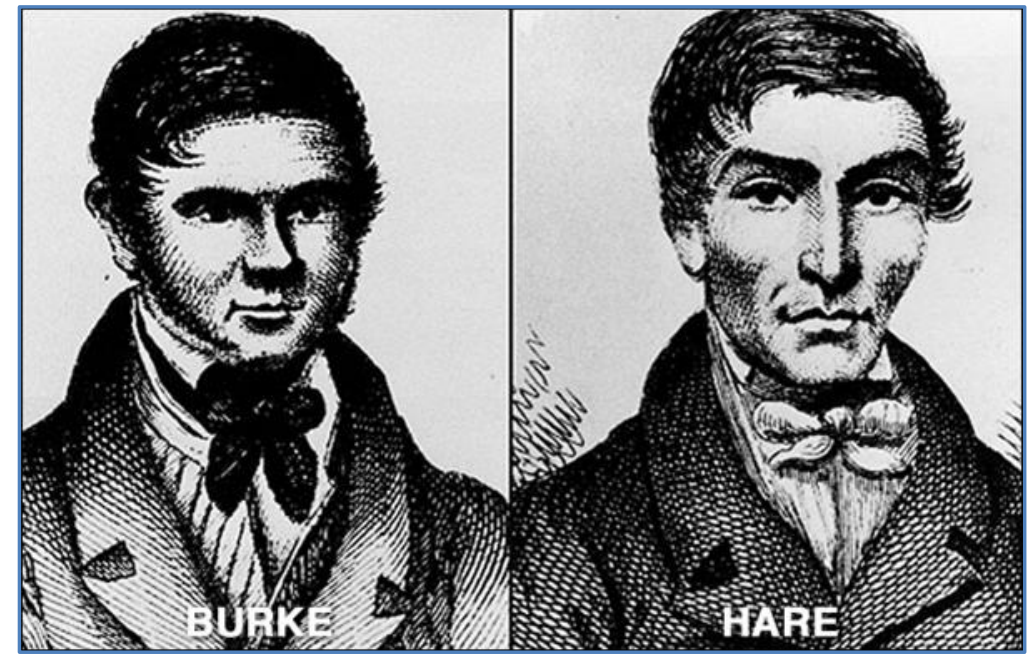

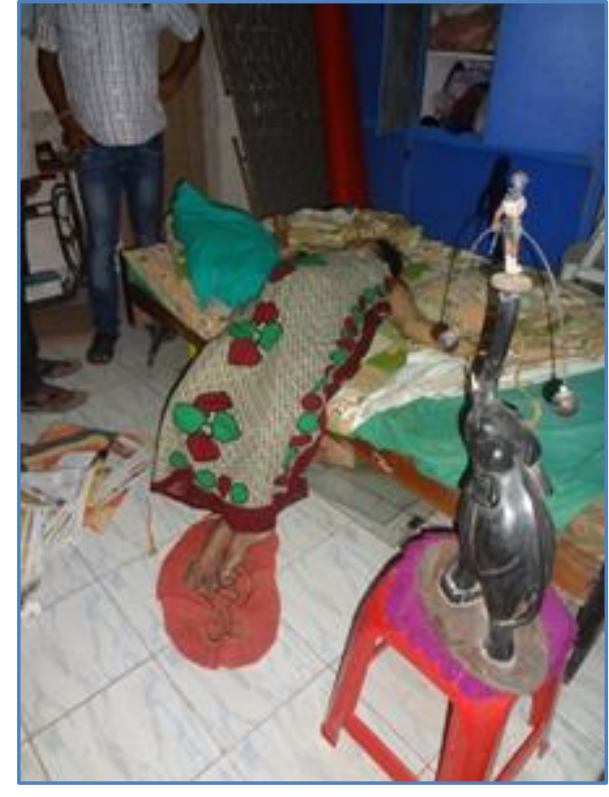

Position of the body found at crime scene

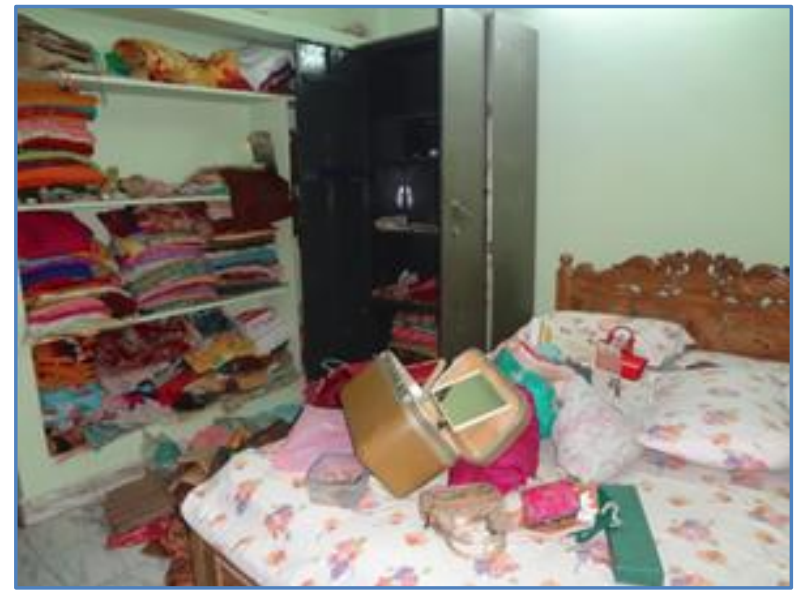

One of the rooms at crime scene 


\section{CASE REPORT}

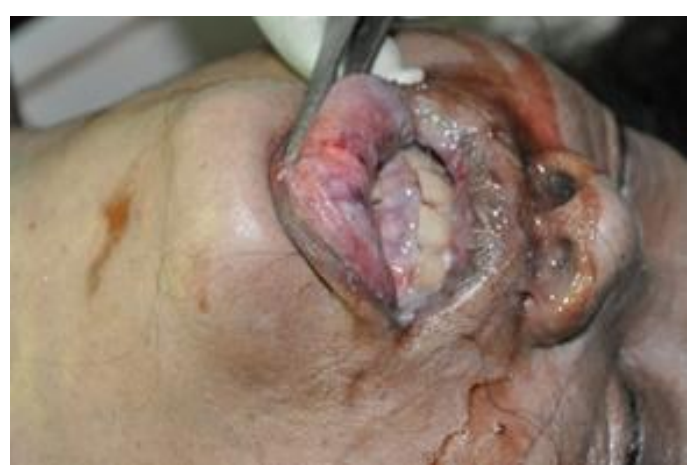

Mucosal surface of lips showing contusions

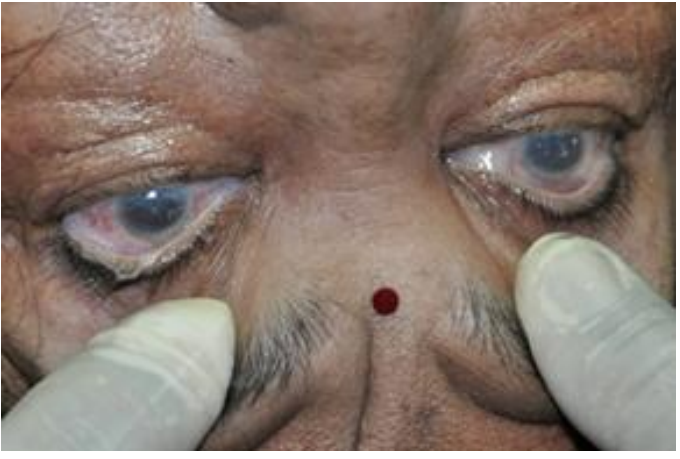

Eyes with petechial haemorrhages

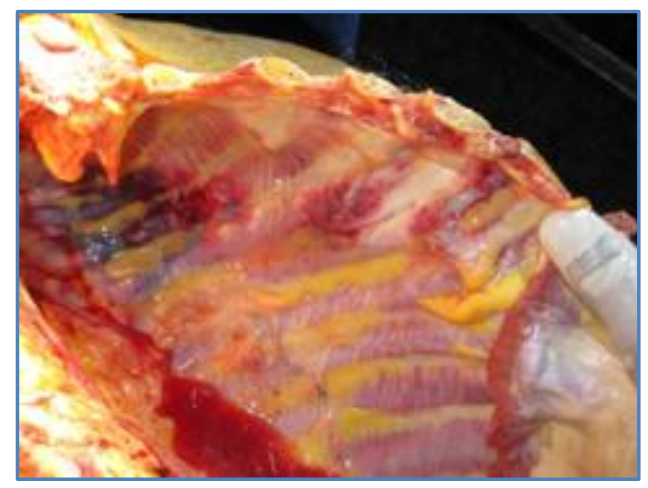

Ribs fractured

\section{REFERENCES:}

1. Dr. K.S. Narayan Reddy. The Essentials of Forensic Medicine and Toxicology. 13th edition, publisher: K.Suguna Devi, hyderabad, Ch10- Pg. 264-265.

2. Statistics Canada, CANSIM, Table 253-0002, Homicide Survey, Canadian Centre for Justice Statistics.

3. Pilay, V V, Textbook of Forensic Medicine and Toxicology. 16th edition. s.l.: Paras medical publisher, Hyderabad, 2011, Ch 14, Pg. 260-286.

4. Apurba Nandy. Priciples of Forensic Medicine Including Toxicology, 3rd edition, publisher: new central book agency (p) ltd., New Delhi, 2011 - Ch 16, Pg 517-564.

5. Bernard Knight, Pekka Saukko. Knight's Forensic Pathology, $3^{\text {rd }}$ edition, publisher: Saffron House, London, 2004, Ch. 8, Pg, 352-367.

6. J K Mason, B N Prude. The Pathology of Trauma, $3^{\text {rd }}$ edition, publisher: Holder headline group, London, 2000, Ch. 15, Pg. 230-253. 


\section{CASE REPORT}

\section{AUTHORS:}

1. D. Durga Prasad

\section{PARTICULARS OF CONTRIBUTORS:}

1. Assistant Professor, Department of Forensic Medicine and Toxicology, Rangaraya Medical College, Kakinada.

\section{NAME ADDRESS EMAIL ID OF THE} CORRESPONDING AUTHOR:

Dr. D. Durga Prasad, \#2-114, Sri Nilayam,

Cheediga, Kakinada Rural, East Godavari District, Andhra Pradesh.

Email: dara.ravivarma@gmail.com

Date of Submission: 04/08/2014.

Date of Peer Review: 05/08/2014.

Date of Acceptance: 21/08/2014.

Date of Publishing: 28/08/2014. 